\title{
Analisis Pengaruh Mekanisme Passive Variable- Pitch pada Turbin Sumbu Vertikal Darrieus Cascade Terhadap Efisiensi Turbin Hidrokinetik Berbasis Computational Fluid Dynamics
}

\author{
Choirun Nisaa Firdausy, Ridho Hantoro, dan Nur Laila Hamidah \\ Departemen Teknik Fisika, Fakultas Teknologi Industri, Institut Teknologi Sepuluh Nopember (ITS) \\ e-mail: choirunnisaafirdausy@gmail.com, hantoro@ep.its.ac.id, nurlaila@its.ac.id
}

\begin{abstract}
Abstrak-Ada banyak cara yang dapat dilakukan untuk meningkatkan performansi turbin hidrokinetik, diantaranya dengan penyusunan blade turbin secara rangkap pada satu lengan, atau biasa disebut dengan cascade dan juga penggunaan mekanisme passive variable - pitch, yaitu mekanisme yang mengatur blade sehingga dapat bergerak dengan sudut tertentu dengan diatur oleh stopper. Pada penelitian sebelumnya telah dilakukan studi eksperimental dan simulasi mengenai pengaruh penggunaan cascade foil terhadap performansi turbin, yang membuktikan bahwa susunan cascade pada turbin dapat meningkatkan performansi turbin. Dalam penelitian ini, dilakukan analisis mengenai pengaruh penggunaan passive variable - pitch pada turbin Darrieus sumbu vertikal yang disusun secara cascade terhadap performansi turbin. Berdasarkan simulasi yang dilakukan dengan metode CFD, didapatkan hasil bahwa semakin besar kecepatan aliran air, akan semakin besar pula nilai gaya dan torsi pada turbin. Namun nilai koefisien performansi (Cp) justru semakin turun seiring dengan peningkatan nilai kecepatan aliran, dimana $\mathrm{Cp}$ terbaik didapatkan pada kecepatan aliran $0,8 \mathrm{~m} / \mathrm{s}$ dengan nilai $\mathrm{Cp}$ sebesar39,76\%. Selain itu, pada penelitian ini juga dilakukan analisis karakteristik aliran, ditinjau dari pola tekanan dan streamline kecepatan untuk mengetahui pengaruh perubahan kecepatan aliran terhadap persebaran kecepatan aliran dan tekanan di sekitar turbin.
\end{abstract}

Kata kunci-Turbin hidrokinetik, darrieus, cascade, passive variable-pitch, CFD, torsi, gaya, karakteristik aliran, Cp.

\section{PENDAHULUAN}

$\mathrm{D}$ ATA Dewan Energi Nasional (DEN) pada 2013 mencatat bahwa potensi EBT terbesar adalah energi dari air sebesar $75.000 \mathrm{MW}$, dengan kapasitas yang terpasang baru sebesar 7573 MW. Dengan kata lain, potensi energi air yang telah dimanfaatkan hingga tahun 2013 baru sebesar 10,1\%. Dan untuk energi laut terdapat potensi sebesar $49 \mathrm{GW}$ dengan kapasitas terpasang baru 0.01 MW [1]. Dari data tersebut, dapat dikatakan bahwa konversi energi dengan memanfaatkan energi air memiliki peluang yang besar untuk membantu memenuhi kebutuhan energi di Indonesia.

Untuk melakukan konversi energi arus air dapat menggunakan turbin. Turbin arus air yang banyak dikembangkan adalah tipe Darrieus dan tipe Gorlov. Dari kedua tipe turbin tersebut, turbin Darrieus lebih unggul dalam beberapa parameter. Konstruksi blade pada turbin Darrieus yang lebih sederhana dibandingkan turbin Gorlov merupakan salah satu kelebihan, karena menyebabkan biaya fabrikasi yang lebih kecil [2]. Selain itu, turbin Darrieus memiliki torsi yang sangat besar pada kecepatan arus tinggi [3] Dalam konversi energi arus laut menjadi energi listrik, untuk mendapatkan energi yang optimal dibutuhkan turbin dengan efisiensi yang tinggi. Pada penelitian sebelumnya, telah dilakukan beberapa upaya untuk meningkatkan efisiensi turbin. Cara yang pertama adalah dengan menguji variasi solidity [4]. Solidity berhubungan dengan luas sapuan turbin, dimana semakin besar luas sapuan turbin akan semakin besar gaya lift yang dihasilkan sehingga torsi akan semakin besar. Metode berikutnya adalah dengan menggunakan blade dengan passive variable-pitch menggantikan blade dengan fixed pitch [5]. Hasil dari penelitian tersebut menunjukkan bahwa penggunaan passive variable-pitch dapat meningkatkan performa turbin yang ditandai dengan peningkatan RPM. Selanjutnya pada penelitian yang dilakukan oleh Niblick pada tahun 2012, disebutkan bahwa turbin Darrieus merupakan lift device, dimana turbin memanfaatkan gaya lift (gaya angkat) untuk berputar. Bagian turbin Darrieus yang menghasilkan gaya lift terbesar adalah blade [6]. Pada penelitian selanjutnya, dilakukan rancang bangun turbin arus laut sumbu vetikal straight blade cascade, dimana pada eksperimen ini dikombinasikan antara fixed pitch dan passive pitch dalam satu turbin, dan didapatkan peningkatan efisiensi sebesar 8\% jika dibandingkan dengan penelitian sebelumnya [7]. Peningkatan efisiensi tersebut terjadi karena turbin yang disusun secara cascade dan mengkombinasikan fixed pitch dengan passive pitch memiliki gaya dan torsi yang lebih besar, serta luasan area yang lebih besar sehingga mendapatkan lebih banyak tekanan [8]. Oleh karena itu. pada penelitian tugas akhir ini, dilakukan simulasi turbin Darrieus menggunakan passive variable-pitch dengan susunan blade rangkap (cascade blade). Diharapkan dari penelitian ini akan didapatkan peningkatan efisiensi turbin Darrieus yang dapat digunakan sebagai referensi untuk pengembangan turbin arus air di masa yang akan datang. 


\section{URAIAN PENELITIAN}

\section{A. Pengumpulan Data}

Sebelum memulai proses simulasi, terlebih dahulu dilakukan pengumpulan data. Dimana data yang dimaksud pada tahap ini adalah data hasil eksperimen yang didapat dari penelitian sebelumnya, yaitu data kecepatan aliran, kecepatan sudut (RPM) turbin, dan torsi. Data kecepatan aliran dan kecepatan sudut tersebut akan digunakan sebagai boundary condition pada simulasi, serta data torsidari hasil eksperimen akan dijadikan acuan validasi hasil simulasi. Selain itu dilakukan juga pengambilan data spesifikasi turbin yang disesuaikan dengan penelitian sebelumnya oleh Argaputra dkk.

Tabel 1.

Spesifikasi Turbin

\begin{tabular}{llr}
\hline \hline No. & \multicolumn{1}{c}{ Besaran } & Nilai \\
\hline 1 & Diameter turbin & $80 \mathrm{~cm}$ \\
2 & Tinggi turbin & $82 \mathrm{~cm}$ \\
3 & Panjang chord & $10 \mathrm{~cm}$ \\
4 & Diameter shaft & $3 \mathrm{~cm}$ \\
5 & Panjang shaft & $82 \mathrm{~m}$ \\
\hline \hline
\end{tabular}

\section{B. Proses Simulasi CFD}

Pembuatan geometri turbin menjadi tahap awal dari proses simulasi CFD. Pada penelitian ini digunakan turbin hidrokinetik vertikal aksis tipe Darrieus straight blade dengan susunan cascade 3 blade. Tipe foil yang digunakan adalah NACA 0018. Detail spesifikasi domain turbin yang digunakan pada penelitian ini dapat dilihat pada tabel 1 .

Pembuatan turbin diawali dengan membuat hydrofoil. Pembuatan foil dilakukan dengan memasukkan file koordinat airfoil NACA 0018. Titik koordinat yang terbentuk nantinya dihubungkan sehingga membentuk garis, kemudian dijadikan permukaan (surface) untuk selanjutnya dijadikan sebuah benda (body). Setelah pembuatan hydrofoil selesai, dilanjutkan dengan pembuatan poros turbin (shaft).

Setelah pembuatan domain turbin selesai, berikutnya dibuat domain silinder. Domain silinder ini menggambarkan keadaan turbin yang berotasi. Untuk domain air, dibuat domain kotak dengan jarak upstream sebesar 1,5D, dimana D merupakan diameter turbin, serta jarak downstream sebesar 2,5D.

Tabel 2.

Spesifikasi Domain Silinder dan Kotak (box)

\begin{tabular}{llr}
\hline \hline \multicolumn{1}{c}{ No. } & \multicolumn{1}{c}{ Besaran } & Nilai \\
\hline 1 & Silinder: & \\
& Diameter & $100 \mathrm{~cm}$ \\
& Tinggi & $120 \mathrm{~cm}$ \\
2 & Kotak: & \\
& Panjang & $400 \mathrm{~cm}$ \\
& Lebar & $160 \mathrm{~cm}$ \\
& Tinggi & $120 \mathrm{~cm}$ \\
\hline \hline
\end{tabular}

Pada proses pembuatan geometri, dilakukan pula penentuan posisi blade yang menggambarkan pergerakan blade dengan sudut pitch sesuai kondisi saat eksperimen. Berdasarkan eksperimen, setiap blade akan menyentuh inner stopper (bergerak $20^{\circ}$ kedalam) saat sudut azimuth berada di antara sudut $0^{\circ}-200^{\circ}$. Sedangkan setiap blade akan menyentuh outer stopper (bergerak $20^{\circ}$ keluar) saat sudut azimuth berada di antara sudut $200^{\circ}-360^{\circ}$. Ketika blade tepat pada sudut azimuth $0^{\circ}, 200^{\circ}$ dan $360^{\circ}$, posisi blade berada tepat di tengah antara inner stopper dan outer stopper.

\begin{tabular}{|c|c|c|c|c|}
\hline Posisi & Sudut & $\begin{array}{c}\text { Inner } \\
\text { Stopper }\end{array}$ & $\begin{array}{l}\text { Middle } \\
\text { Stopper }\end{array}$ & $\begin{array}{c}\text { Outer } \\
\text { Stopper }\end{array}$ \\
\hline \multirow{3}{*}{1} & 0 & & $\mathrm{~V}$ & \\
\hline & 120 & v & & \\
\hline & 240 & & & v \\
\hline \multirow{3}{*}{2} & 15 & V & & \\
\hline & 135 & V & & \\
\hline & 255 & & & v \\
\hline \multirow{3}{*}{3} & 30 & v & & \\
\hline & 150 & v & & \\
\hline & 270 & & & V \\
\hline \multirow{3}{*}{4} & 45 & v & & \\
\hline & 165 & v & & \\
\hline & 285 & & & V \\
\hline \multirow{3}{*}{5} & 60 & V & & \\
\hline & 180 & v & & \\
\hline & 300 & & & V \\
\hline \multirow{3}{*}{6} & 75 & v & & \\
\hline & 195 & V & & \\
\hline & 315 & & & v \\
\hline \multirow{3}{*}{7} & 90 & v & & \\
\hline & 210 & & & v \\
\hline & 330 & & & v \\
\hline \multirow{3}{*}{8} & 105 & V & & \\
\hline & 225 & & & v \\
\hline & 345 & & & V \\
\hline
\end{tabular}

Setelah proses pembuatan geometri selesai, dilakukan proses meshing. Pada proses ini dilakukan pemecahan domain menjadi bagian - bagian kecil, dimana masing masing bagian dianggap sebagai sebuah control volume. Pada setiap bagian tersebut nantinya akan dilakukan perhitungan persamaan konversi energi, massa, momentum, dan persamaan lainnya menggunakan software untuk CFD. Semakin kecil ukuran meshing, akan semakin akurat hasil perhitungan, namun akan membutuhkan komputasi yang berat. Selain jumlah elemen, jenis mesh juga mempengaruhi kualitas mesh serta keakuratan perhitungan hasil simulasi. Untuk penelitian ini, jenis mesh yang sesuai adalah bentuk tetrahedral. Ukuran elemen mesh yang digunakan dalam simulasi ini adalah $3 \mathrm{~mm}$ untuk blade dan shaft, serta $50 \mathrm{~mm}$ untuk interface.

Selanjutnya adalah tahap pre-processing. Tahap ini merupakan tahap untuk mendefinisikan kondisi batas (boundary condition). Kondisi batas yang digunakan disesuaikan dengan kondisi saat eksperimen agar mendapatkan hasil simulasi yang sesuai, seperti kecepatan aliran pada inlet dan kecepatan rotasi turbin. Selain itu, perlu juga mendefinisikan model turbulensi yang digunakan. Untuk penelitian ini, digunakan model turbulensi SST.

Setelah proses pre-processing selesai, dilanjutkan dengan proses processing atau solver. Proses solver atau processing merupakan proses perhitungan berdasarkan 
geometri, meshing, serta kondisi batas yang telah ditentukan sebelumnya. Proses perhitungan dilakukan dengan cara iterasi hingga mendapatkan nilai yang konvergen ketika nilai RMS residual error telah mencapai 0.0001 .

Setelah melalui tahap processing atau solver, dilanjutkan dengan proses post processing. Proses ini adalah proses terakhir dari simulasi. Pada proses ini dilakukan pengambilan data, berupa data gaya dan torsi. Selain itu, pada proses ini juga dapat ditampilkan karakteristik aliran berupa kontur tekanan serta streamline kecepatan aliran.

\section{Analisa Data Simulasi}

Data yang didapat kemudian dianalisis sesuai dengan teori yang berkaitan. Untuk menghitung efisiensi turbin, terlebih dahulu dilakukan perhitungan nilai Coefficient of Power (Cp) menggunakan persamaan:

$$
C p=\frac{\text { Pturbin }}{\text { Pair }}=\frac{\pi \times w}{\frac{1}{2} \rho A v^{3}}
$$

Cp menggambarkan kemampuan turbin untuk mengekstraksi daya dari aliran air. Semakin besar nilai $\mathrm{Cp}$, semakin baik performansi turbin. Kemudian untuk mendapatkan nilai efisiensi, digunakan persamaan:

$$
\eta=C p \times 100 \%
$$

\section{HASIL DAN DISKUSI}

\section{A. Validasi Hasil Simulasi CFD}

Validasi adalah proses untuk mendapatkan hasil simulasi yang paling mendekati kondisi sebenarnya untuk memastikan kebenaran model simulasi. Pada penelitian ini, validasi dilakukan dengan cara membandingkan nilai torsi turbin yang didapatkan dari simulasi dengan hasil eksperimen. Untuk mendapatkan nilai yang mendekati kondisi sebenarnya, maka kondisi batas yang digunakan pada simulasi disesuaikan dengan kondisi saat eksperimen. Validasi juga dipengaruhi oleh ukuran mesh saat simulasi, karena ukuran mesh berkaitan dengan perhitungan yang lebih detail.

Validasi pada penelitian ini dilakukan pada salah satu kecepatan aliran yaitu pada kecepatan $0,8 \mathrm{~m} / \mathrm{s}$. Ukuran mesh 3 mm untuk shaft dan blade serta 50 mm untuk interface. Dari hasil simulasi didapatkan nilai torsi sebesar 17,5945 Nm dan nilai torsi dari eksperimen adalah 17,2069 Nm, sehingga nilai error yang didapatkan adalah 2,3\%. Dengan nilai error yang kurang dari $10 \%$, dapat dikatakan data yang didapat dari simulasi telah tervalidasi. Selanjutnya dilakukan simulasi untuk kecepatan aliran 1,2 m/s dan 1,6 m/s.

\section{B. Pengumpulan Data}

Simulasi dilakukan pada 3 variasi kecepatan, yaitu $0,8 \mathrm{~m} / \mathrm{s}$, $1,2 \mathrm{~m} / \mathrm{s}$, dan $1,6 \mathrm{~m} / \mathrm{s}$. Kecepatan $1,2 \mathrm{~m} / \mathrm{s}$ dan $1,6 \mathrm{~m} / \mathrm{s}$ didapatkan dari hasil ekstrapolasi data hasil eksperimen. Hal tersebut dilakukan untuk mengetahui performansi turbin Darrieus cascade pada kecepatan aliran yang lebih tinggi. Pada setiap variasi kecepatan dilakukan simulasi setiap sudut azimuth $15^{0}$ untuk satu putaran penuh. Dari simulasi setiap sudut azimuth tersebut diambil data torsi, gaya, serta karakteristik aliran berupa kontur tekanan serta streamline kecepatan.
Tabel 4.

Data Kecepatan Aliran Air dan Kecepatan Putaran Turbin Hasil

\begin{tabular}{|c|c|c|c|}
\hline $\begin{array}{l}\text { Kecepatan } \\
(\mathrm{m} / \mathrm{s})\end{array}$ & Aliran & $\begin{array}{r}\text { Kecepatan } \\
\text { Turbin (RPM) }\end{array}$ & Putaran \\
\hline 0,8 & & 36,3750 & \\
\hline 1,2 & & 54,5393 & \\
\hline 1,6 & & 72,9301 & \\
\hline
\end{tabular}
Ekstrapolasi

C. Nilai Gaya dan Torsi pada Variasi Kecepatan Aliran Air

Pengambilan data gaya dan torsi dilakukan pada setiap sudut azimuth $15^{0}$, sehingga untuk satu putaran penuh terdapat 24 titik pengambilan data. Namun untuk simulasi hanya dilakukan 8 kali simulasi untuk satu kali putaran, karena terjadi kesamaan posisi blade, dimana pada saat blade 1 berada pada sudut azimuth $120^{\circ}$, blade 2 pada azimuth $240^{\circ}$, dan blade 3 pada sudut azimuth $0^{\circ}$, posisi ini sama seperti ketika blade 1 berada pada sudut azimuth $0^{\circ}$. Sehingga saat pengambilan data pada sudut azimuth $0^{0}$, didapatkan juga data untuk sudut azimuth $120^{\circ}$ dan $240^{\circ}$. Begitu pula untuk sudut azimuth $15^{\circ}, 30^{\circ}, 45^{\circ}, 60^{\circ}, 75^{\circ}, 90^{\circ}$, dan $105^{\circ}$. Dari hasil simulasi, didapatkan peningkatan nilai gaya dan torsi seiring dengan kenaikan kecepatan aliran.

Berdasarkan hasil simulasi yang telah dilakukan, dari ketiga variasi kecepatan didapatkan bahwa nilai gaya paling optimal didapatkan pada posisi sudut azimuth $90^{\circ}, 210^{\circ}$, dan $330^{\circ}$, seperti ditunjukkan grafik pada gambar 1.

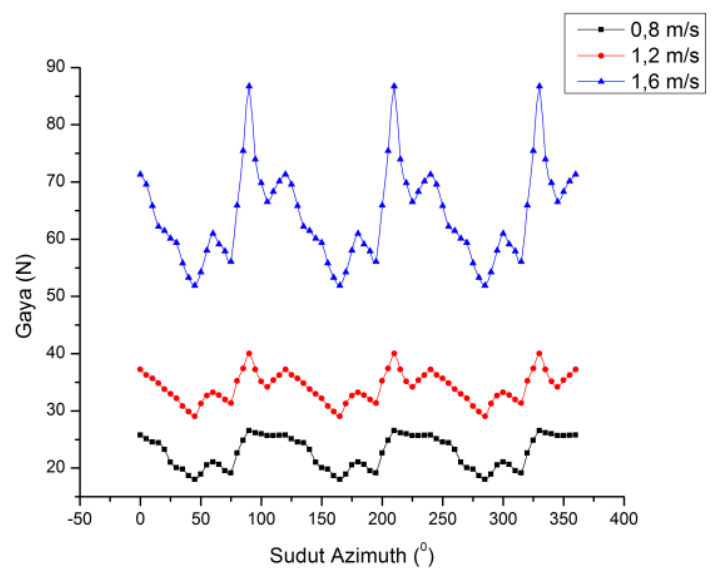

(a)

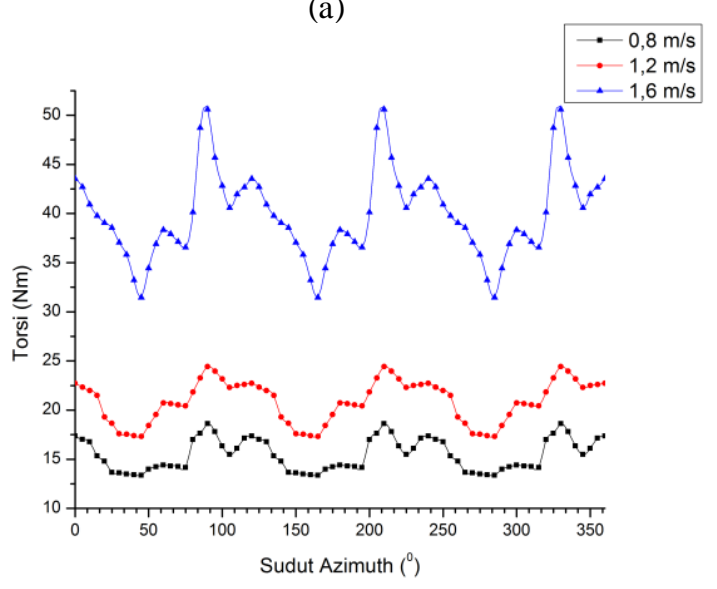

(b)

Gambar 1. Grafik perubahan (a) gaya dan (b) torsi pada kecepatan 0,8 $\mathrm{m} / \mathrm{s}, 1,2 \mathrm{~m} / \mathrm{s}$, dan $1,6 \mathrm{~m} / \mathrm{s}$ 
Karena pada sudut azimuth $90^{\circ}, 210^{\circ}$ dan $330^{\circ}$, posisi blade pada sudut tersebut memungkinkan terjadinya kontak antara permukaan blade dengan air yang paling luas. Semakin besar luas area sapuan, akan semakin besar pula gaya yang dihasilkan. Peningkatan gaya akan disertai dengan peningkatan torsi, karena torsi didapat dari perkalian nilai gaya dengan lengan gaya (dalam hal ini yang dimaksud adalah lengan turbin), dimana torsi berbanding lurus dengan gaya. Selain itu, nilai gaya dan torsi mengalami pening katan seiring dengan adanya peningkatan kecepatan aliran air. Nilai gaya dan torsi turbin berbanding lurus dengan kuadrat kecepatan aliran air. Sehingga semakin besar kecepatan aliran, akan semakin besar nilai gaya dan torsi yang dihasilkan turbin.

\section{Karakteristik Aliran}

Untuk penelitian ini, dilakukan pengambilan data kontur tekanan dan streamline kecepatan untuk mengetahui persebaran tekanan dan pola aliran yang terjadi di sekitar turbin.

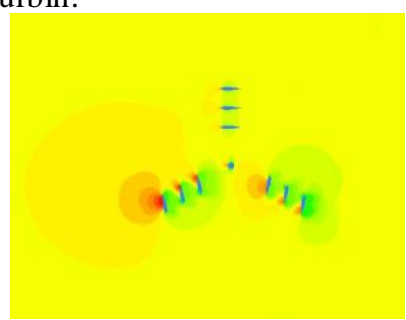

(a)

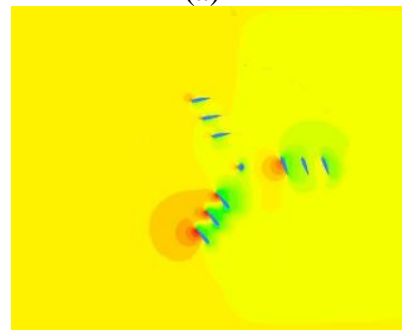

(c)

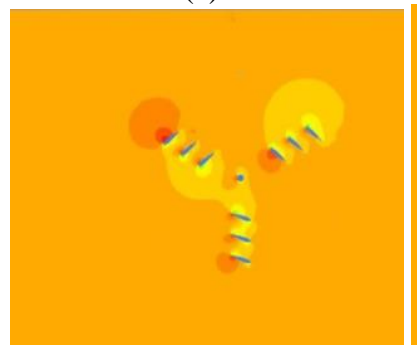

(e)

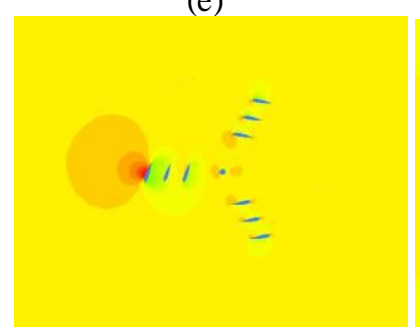

Gambar 2. Kontur tekanan pada sudut azimuth: (a) $0^{\circ}$, (b) $15^{\circ}$, (c) $30^{\circ}$, (d) $45^{\circ}$, (e) $60^{\circ}$, (f) $75^{\circ}$, (g) $90^{\circ}$, dan (h) $105^{\circ}$ saat kecepatan aliran air $1,6 \mathrm{~m} / \mathrm{s}$

Gambar 2 menggambarkan distribusi tekanan pada sudut azimuth yang digunakan sebagai titik pengambilan data gaya dan torsi. Dari delapan sudut azimuth tersebut, didapatkan gaya paling besar pada sudut azimuth $90^{\circ}$, dimana pada azimuth tersebut jika dilihat dari kontur tekanan juga memiliki nilai tekanan paling besar dibandingkan yang lain. Nilai tekanan terbesar pada sudut ini adalah $1013,8324 \mathrm{~Pa}$.

Pressure

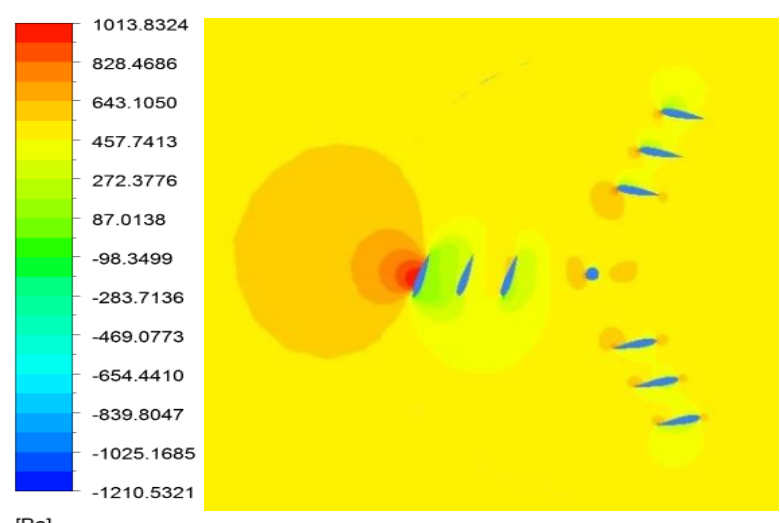

[Pa]

Gambar 3.Kontur tekanan azimuth $90^{\circ}$

Selain kontur tekanan, dilihat pula streamline kecepatan di sekitar turbin. Gambar 4 menunjukkan streamline kecepatan pada sudut azimuth yang sama seperti pada saat pengambilan kontur tekanan.

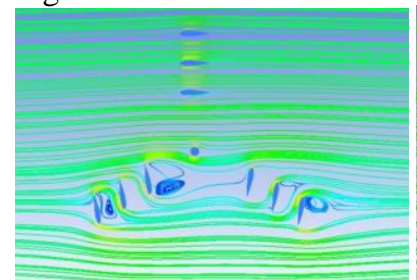

(a)

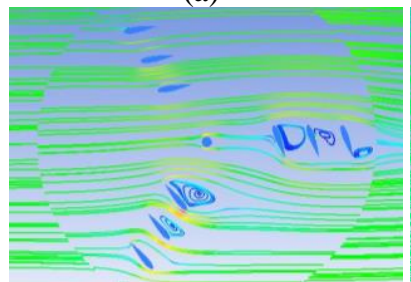

(c)

(e)

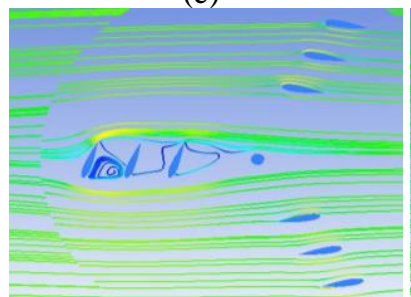

(g)

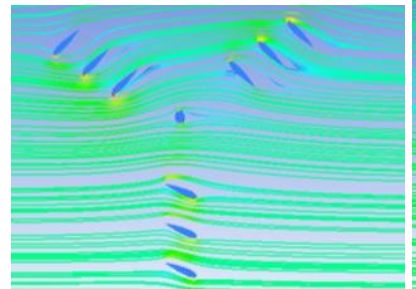

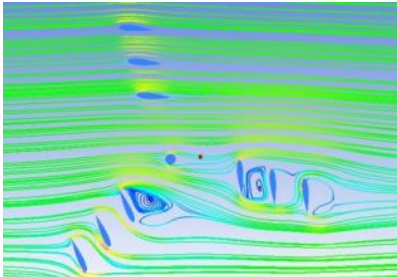

(b)

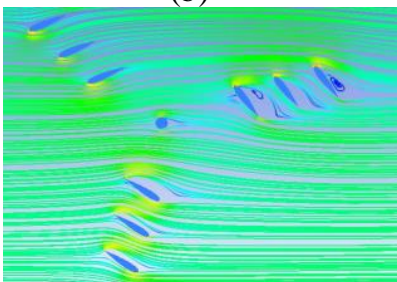

(d)

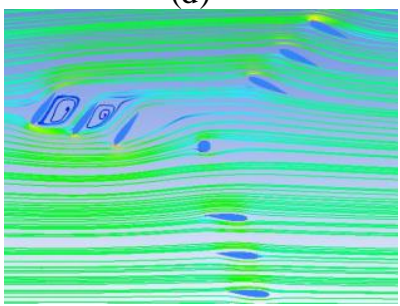

(f)

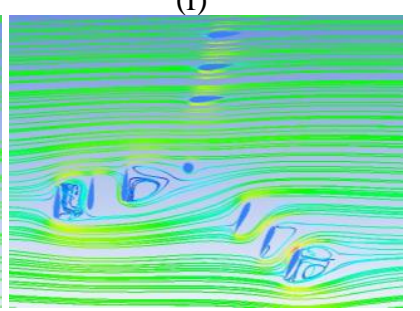

(h)
Gambar 4. Pola kecepatan aliran pada sudut azimuth: (a) $00^{\circ}$, (b) $15^{\circ}$, (c) $30^{\circ}$, (d) $45^{\circ}$, (e) $60^{\circ}$, (f) $75^{\circ}$, (g) $90^{\circ}$, dan (h) $105^{\circ}$

Pada sudut azimuth $90^{\circ}$, terjadi penurunan kecepatan aliran yang paling signifikan saat sebelum melewati blade dan sesudah melewati blade. Penurunan kecepatan aliran terjadi di belakang setiap blade. Kecepatan aliran tertinggi 
yang melewati turbin pada sudut azimuth $90^{\circ}$ adalah 2,9616 $\mathrm{m} / \mathrm{s}$ dan kecepatan aliran terendah adalah $0,0023 \mathrm{~m} / \mathrm{s}$ yang terjadi dibelakang blade lengan ketiga (posisi sudut azimuth $\left.285^{0}\right)$.

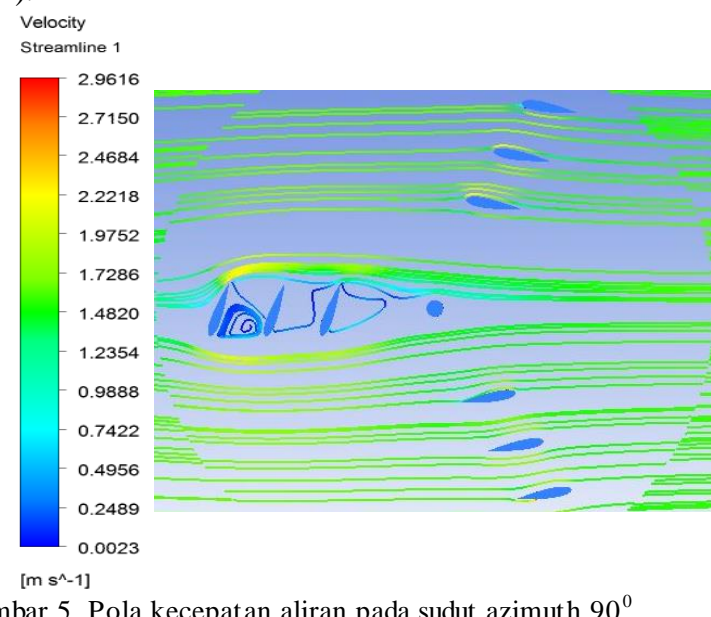

Gambar 5. Pola kecepatan aliran pada sudut azimuth $90^{\circ}$

Dari gambar diatas, terlihat bahwa tekanan mengalami peningkatan sebelum aliran air melewati blade. Peningkatan tekanan ini diikuti dengan adanya penurunan kecepatan aliran saat mengenai turbin. Hal ini sesuai dengan hukum bernoulli, dimana nilai tekanan berbanding terbalik dengan kecepatan. Dan bila dilihat secara keseluruhan, kecepatan aliran yang telah melewati turbin dengan passive variable pitch lebih cepat stabil. Hal ini menunjukkan bahwa penggunaan passive variable pitch dapat memperkecil daerah near wake.

\section{E. Performansi Turbin}

Untuk mempermudah menilai performansi turbin, dilakukan perhitungan untuk mendapatkan nilai $\mathrm{Cp}$. Seperti yang telah diketahui, Cp merupakan bilangan non dimensional yang menyatakan kemampuan turbin dalam menghasilkan energi yang didapat dari ekstraksi daya air. Semakin besar nilai $\mathrm{Cp}$ akan semakin baik performansi turbin tersebut. Berdasarkan standar yang biasa disebut dengan Betz limit, performansi turbin jenis vertikal aksis paling optimal adalah dengan efisiensi sebesar 59.3\%. Dari hasil simulasi ini, didapatkan nilai Cp tertinggi sebesar 0,3976 atau dapat dikatakan efisiensinya adalah $39,76 \%$. Nilai tersebut didapat pada kecepatan aliran $0,8 \mathrm{~m} / \mathrm{s}$. Selanjutnya terjadi penurunan performansi bila dibandingkan dengan nilai $\mathrm{Cp}$ pada saat kecepatan aliran $0,8 \mathrm{~m} / \mathrm{s}$, yaitu sebes ar 0,2238 pada kecepatan aliran $1,2 \mathrm{~m} / \mathrm{s}$ dan 0,2187 pada kecepatan aliran $1,6 \mathrm{~m} / \mathrm{s}$, seperti ditunjukkan pada gambar 6 .

Meninjau dari hasil penelitian sebelumnya oleh Seno Widya Manggala pada 2016, performansi yang didapat juga mengalami penurunan seiring dengan peningkatan kecepatan aliran air, yang dibuktikan dengan penurunan nilai $\mathrm{Cp}$. Penurunan performansi ini menandakan bahwa turbin telah melewati batas maksimal kemampuan untuk melakukan ekstraksi energi. Selain itu, performansi yang didapatkan pada penelitian ini lebih rendah dibandingkan hasil penelitian sebelumnya, dimana pada penelitian sebelumnya passive variable pitch hanya digunakan pada blade terluar turbin Darrieus cascade. Sedangkan pada penelitian ini semua blade menggunakan passive variable pitch. Seperti pada saat kecepatan 1,2 m/s, dari hasil penelitian Seno didapatkan nilai Cp sebesar 0,35 sedangkan dari hasil penelitian ini nilai
Cp yang didapatkan adalah 0,2138. Adanya penurunan performansi ini disebabkan karena penggunaan passive variable pitch berdampak pada nilai peak efficiency yang cenderung turun, seperti yang disebutkan dalam hasil penelitian M. A. Singh dkk.

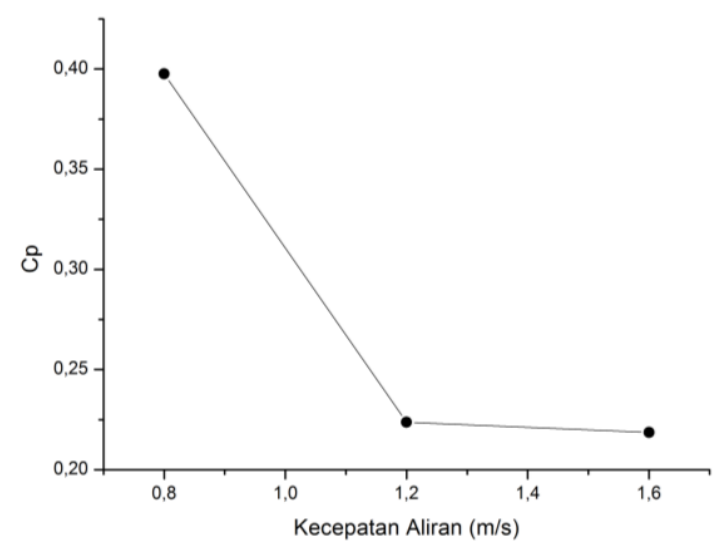

Gambar 6. Grafik nilai koefisien performansi turbin (Cp) terhadap kecepatan aliran air

Maka, bila melihat dari hasil perhitungan performansi pada penelitian ini, dapat disimpulkan bahwa performansi terbaik untuk turbin hidrokinetik Darrieus sumbu vertikal yang disusun secara cascade dengan passive variable pitch adalah pada kecepatan aliran rendah, yaitu $0,8 \mathrm{~m} / \mathrm{s}$ dengan nilai Cp 0,3976 atau efisiensi 39,76\%. Dan performansi tersebut akan turun seiring dengan kenaikan kecepatan aliran. Atau dapat dikatakan bahwa turbin hidrokinetik Darrieus sumbu vertikal yang disusun secara cascade dengan passive variable pitch lebih cocok untuk diaplikasikan pada perairan dengan kecepatan aliran rendah.

\section{KESIMPULAN/RINGKASAN}

Berdasarkan penelitian yang telah dilakukan, dapat ditarik beberapa kesimpulan sebagai berikut:

- Penggunaan mekanisme passive variable pitch pada turbin hidrokinetik Darrieus sumbu vertikal dengan susunan cascade dapat meningkatkan nilai torsi dan gaya turbin seiring dengan kenaikan nilai kecepatan aliran, dengan nilai torsi dan gaya terbesar didapat pada kecepatan aliran 1,6 $\mathrm{m} / \mathrm{s}$, yaitu $86,7356 \mathrm{~N}$ untuk gaya dan 50,5919 Nm untuk torsi

- Performansi terbaik dari turbin hidrokinetik Darrieus sumbu vertikal yang disusun secara cascade dengan passive variable pitch didapatkan pada kecepatan aliran $0,8 \mathrm{~m} / \mathrm{s}$, yaitu dengan nilai Cp 0,3976 atau efisiensi 39,76\%, dan akan turun seiring dengan semakin besarnya kecepatan aliran

- Turbin hidrokinetik Darrieus sumbu vertikal dengan susunan cascade yang menggunakan mekanisme passive variable pitch lebih sesuai untuk diaplikasikan pada kecepatan aliran rendah.

\section{UCAPAN TERIMA KASIH}

Penulis mengucapkan terima kasih kepada Laboratorium Rekayasa Energi dan Pengkondisian Lingkunga yang telah memfasilitasi penelitian ini. Penulis juga mengucapkan terima kasih kepada Bapak Dr. Ridho Hantoro S.T., M.T. dan Ibu 
Nur Laila Hamidah S.T., M.Sc., selaku dosen pembimbing yang mendampingi dan banyak memberikan masukan selama pengerjaan tugas akhir, serta kepada semua pihak yang banyak memberikan bantuan kepada penulis.

\section{DAFTAR PUSTAKA}

[1] D. E. Nasional, “Outlook Energi Indonesia 2014,” Jakarta, 2014.

[2] S. Winchester, J., \& Quayle, "Torque Ripple and Variable Blade Force: A Comparison of Darrieus and Gorlov-Type Turbines for Tidal Stream Energy Conversion," in The 8th European Wave and Tidal Energy Conference, 2009.

[3] D. Jaini, Kaprawi, \& Santoso, "Darrieus Water turbine Performance Configuration of Blade," J. Mech. Sci. Eng., vol. 2, no. 1, pp. 7-11, 2015.

[4] S. Shiono, M., Suzuki, K., \& Kiho, "Output Characteristics of Darrieus Water Turbine with Helical Blades for Tidal Current Generations," in Proceeding of the 12th International Offshore and Polar Engineering Conference, 2002, pp. 859-864.

[5] A. Hantoro, R., Utama, I., Erwandi, \& Sulisetyono, “An Experimental Investigation of Passive Variable-Pitch Vertical-Axis Ocean Current Turbine," ITB J. Eng. Sci., vol. 43, no. 1, pp. 27-40, 2011.

[6] A. L. Niblick, "Experimental and Analytical Study of Helical Cross-Flow Turbines for a Tidal Micropower Generation System," 2012.

[7] S. W. Manggala, "Rancang Bangun Turbin Arus Laut Sumbu Vertikal Straight Blade Cascade untuk Mengetahui Pengaruh Variasi Jumlah Blade Terhadap Efisiensi Turbin,” IT S, 2016.

[8] F. Imanuddin, "Studi Numerik Pengaruh Jumlah Hydrofoil Terhadap Karakteristik Turbin Arus Laut Vertikal aksis Jenis Straight Blade Berbasis Computational Fluid Dynamics," 2016 . 